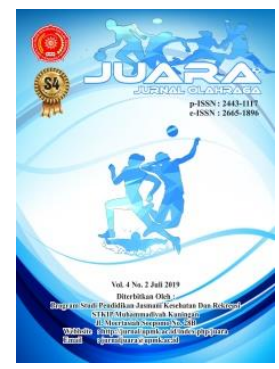

\title{
Analisis Pengetahuan dan Partisipasi Siswa Sekolah Dasar Terhadap Permainan
} Tradisional

\section{The Analysis of Primary School Student Knowledge and Participation towards Traditional Games}

Gustiana Mega Anggita ${ }^{1}$, Mohammad Arif Ali², Sugiarto ${ }^{3}$, Siti Baitul Mukarromah ${ }^{4}$ ${ }_{1,2,3,4}$ Faculty of Sport Science, Universitas Negeri Semarang, Sekaran, Kec. Gn. Pati, Kota Semarang, Jawa Tengah 50229, Indonesia

Email: mega.anggita@mail.unnes.ac.id ${ }^{1}$, hiarifalikhan@mail.unnes.ac.id ${ }^{2}$, $\underline{\text { sugiarto.edu@mail.unnes.ac.id }}^{3}$, sitibaitul@mail.unnes.ac.id ${ }^{4}$

\section{Info Artikel}

Sejarah Artikel:

Diterima 26 Oktober 2019

Disetujui 21 Desember 2019

Dipublikasikan 28 Desember 2019

Keywords:

Participation,

Elementary School

Students, Traditional

Games

\begin{abstract}
Abstrak
Tujuan penelitian ini adalah untuk menganalisis pengetahuan dan partisipasi siswa MI terhadap permainan tradisional. Penelitian ini adalah deskriptif kuantitatif. Sampel dalam penelitian ini adalah siswa kelas atas MI Nurul Yaqien. Instrument penelitian yang digunakan adalah kuisioner. Teknik analisis data yang digunakan yaitu persentase atau procentage correction. Hasil penelitian menunjukkan sebesar $94.44 \%$ siswa mengetahui permainan tradisional. Sebesar $71.43 \%$ siswa memahami permainan tradisional. Sebesar $91.67 \%$ siswa terlibat dalam permaian tradisional. Kesimpulan dari penelitian ini yaitu pengetahuan dan partisipasi siswa MI Nurul Yaqien terhadap permainan tradisional sangat baik. Sedangkan pemahaman tentang permainan tradisional berada pada kategori cukup.
\end{abstract}

\begin{abstract}
This study aims to analysis elementary students' understanding and participation in traditional game. This is a descrivtive research using survey method. Sample in this study was upper class students of MI Nurul Yaqien. The research instrument used was a questionnaire. Data analysis technique used is percentage or procentage correction. The results showed that $94.44 \%$ of students know traditional games. $71.43 \%$ of students understand traditional games. $91.67 \%$ of students are involved in traditional games. Conclusion of this research is the knowledge and participation of MI Nurul Yaqien students in traditional games is excellent. While their understanding of traditional games is in the sufficient category.
\end{abstract}

(C) 2020 Gustiana Mega Anggita, Mohammad Arif Ali, Sugiarto, Siti Baitul Mukarromah Under the license CC BY-SA 4.0

\footnotetext{
Alamat korespondensi: Sekaran, Kec. Gn. Pati, Kota Semarang, Jawa Tengah

E-mail : mega.anggita@mail.unnes.ac.id

No Handphone : 085643688880
} 


\section{PENDAHULUAN}

Perkembangan Ilmu Pengetahuan dan Teknologi (IPTEK) saat ini mengalami kemajuan yang pesat. Kemajuan IPTEK berdampak hampir pada semua aspek kehidupan dan dirasakan oleh seluruh lapisan masyarakat. Jenis-jenis pekerjaan yang sebelumnya menuntut kemampuan fisik yang cukup besar, kini relative sudah dapat digantikan oleh perangkat mesin-mesin otomatis. Hal tersebut merupakan salah satu dari manfaat dari kemajuan ilmu pengetahuan dan teknologi (IPTEK) khususnya dibidang teknologi digital (Ngafifi, 2014). Tidak dapat dipungkiri bahwa kemajuan IPTEK memberikan segala kemudahan bagi masyarakat. Inovasi-inovasi yang dihasilkan dari kemajuan IPTEK meliputi hampir semua aspek kehidupan mulai dari pendidikan, kesehatan, olahraga, fashion, pekerjaan dan masih banyak lagi. Teknologi dan inovasi tersebut membuat segala aktivitas yang dilakukan umat manusia menjadi lebih mudah dan praktis. Oleh karena itu, seiring dengan kemajuan IPTEK masyarakat pun dibuat terlena dengan kemudahan yang diberikan dan terperangkap di dalamnya. Kemajuan teknologi diera globalisasi ini melaju sangat cepat, manusia kadangkala tidak memiliki cukup waktu untuk beradaptasi dengan perubahan yang terjadi. Hal tersebut menyebabkan masyarakat menjadi hilang arah tidak memiliki pegangan hidup yang jelas. Masyarakat yang tidak mampu beradaptasi dan menguasai teknologi akan terancam eksistensinya dan mengalami cultural lag (Ngafifi, 2014).

Perkembangan dan kemajuan IPTEK yang begitu pesat ternyata mempengaruhi aktivitas fisik yang dilakukan oleh anak-anak. Aktivitas fisik sangat penting bagi kesehatan manusia dalam melakukan kegiatan seharihari. Kegemukan (obesitas) terjadi akibat kurangnya aktivitas fisik dan seringnya menghabiskan waktu untuk bermain game online maupun ofline, menonton televisi dan internetan berlebihan (Effendi \& Prihanto, 2014). Kemajuan IPTEK ini memberikan fasilitas bermain untuk anak melalui permainan digital atau biasanya disebut dengan nama game online. Melaui game online anak mendapatkan pengalaman bermain tanpa harus repot menyiapkan peralatan, mencari teman bermain dan bersusah payah mengeluarkan energi sehingga pada masa kini jarang sekali ditemukan anak-anak yang bergerak aktif dalam bermain. Saat ini kebutuhan bermain anak digantian oleh produk dari kemajuan IPTEK. Anak yang mengalami obesitas cenderung tidak banyak bergerak, cenderung hanya duduk di depan televisi dan bermain dengan memanfaatkan media. anak bermain permainan yang sudah memanfaatkan teknologi (Irfansyah, 2015).

Bermain merupakan aktivitas fisik yang menyenangkan. Bermain merupakan suatu aktivitas yang dapat diartikan sebagai interaksi dengan orang, hewan atau barang dalam konteks pembelajaran. Bermain juga dapat dikatakan sebagai salah satu sarana rekreasi (Mega Anggita \& Amirullah Rachman, 2014). Bermain merupakan cara alamiah anak untuk menemukan lingkungan, orang lain, dan dirinya sendiri (Mega Anggita \& Amirullah Rachman, 2014). Di tahun-tahun masa kanakkanak, khususnya dalam proses bermain permainan, anak-anak bersiap untuk melakukan segala jenis pembelajaran. Hal tersebut dapat mengembangkan keterampilan adaptasi anak seperti berpikir kreatif, pemecahan masalah, mengatasi, dan perilaku sosial (Aypay, 2016).

Permainan tradisional merupakan salah satu sarana bermain bagi anak. Selain bermanfaat bagi kesehatan, kebugaran dan tumbuh kembang anak, terdapat juga nilainilai positif yang terkandung dalam permainan tradisional misalnya kejujuran, kerjasama, sportif, tolong menolong, tanggung jawab, disiplin dan masih banyak lagi dimana hal-hal tersebut dapat membangun karakter anak. 
Selain itu, Permainan tradisional lebih efektif dari kegiatan sehari-hari dalam rangka untuk mengembangkan control objek, kemampuan lokomotor dan keterampilan dasar (Akbari et al., 2009). Permainan tradisional yang terstruktur sedemikian rupa secara langsung mempengaruhi psikomotor, perkembangan kognitif dan emosional anak. Permainan tradisional dapat mempengaruhi peningkatan kesenangan dari pemain dan positif mempengaruhi perkembangan anak secara keseluruhan (Kovacevic \& Opic, 2014). Permainan tradisonal memiliki manfaat yang banyak dalam kehidupan anak-anak antara lain meningkatkan kebugaran jasmani, meningkatkan keterampilan motorik kasar, melatih kreativitas dalam berpikir dan melatih sportivitas (Charles et al, 2017; Hayati, 2017).

Permainan tradisional merupakan permainan yang di dalamnya terdapat unsur budaya yang melekat dan harus dilestarikan keberadaannya. Permainan tradisional bukan sekedar permainan biasa (Hikmah Prisia Yudiwinata \& Handoyo, 2014). Permainan tradisional adalah salah satu cerita rakyat yang berasal dari masyarakat. Umumnya, permainan tradisional diwarisi dari generasi ke generasi, dimainkan secara tradisional dan didemonstrasikan dengan menggunakan beberapa alat khusus (Ode et al., 2018). Sebagian besar permainan tradisional dan olahraga merupakan ekspresi budaya asli dan cara hidup yang memberikan kontribusi terhadap identitas umum kemanusiaan telah menghilang dan yang masih bertahan juga terancam hilang atau punah karena pengaruh globalisasi dan harmonisasi keragaman warisan olahraga dunia (Boro, Daimary, \& Narzaree, 2015). Sekarang ini permainan tradisional sudah mulai ditinggalkan oleh anak-anak bahkan tidak sedikit anak-anak yang tidak tahu apa itu permainan tradisional. Anak-anak hanya melakukan aktivitas fisik di sekolah sebagai bagian dari proses pendidikan. Hilangnya permainan tradisional disebabkan oleh beberapa faktor yaitu: (a) alat dan tempat bermain tidak tersedia, (b) kurangnya waktu, terlebih lagi semakin kompleknya tuntutan zaman terhadap anak yang semakin membebani, (c) permainan tradisional terdesak oleh permainan modern dari luar negeri dimana tidak memakan tempat, tak terkendala waktu baik itu siang hari, pagi, sore ataupun malam bisa dilakukan serta tidak perlu menunggu orang lain untuk bermain, (d) terputusnya pewarisan budaya yang dilakukan oleh generasi sebelumnya dimana mereka tidak sempat mencatat, mendata dan mensosialisasikan sebagai produk budaya masyarakat kepada generasi dibawahnya (Tedi, 2015). Selain itu, Permainan tradisional jarang dimainkan pada jam istirahat sekolah dan class meeting, hal tersebut terjadi karena beberapa hambatan yang berhubungan dengan kurangnya ruang dan waktu untuk bermain di sekolah karena jumlah jumlah siswa di kelas yang banyak dan sedikitnya ruang untuk bermain (Kovacevic \& Opic, 2014). Oleh karena itu, pelestarian permainan tradisional menjadi hal penting untuk menjaga keberlangsungan permainan tradisional diera digitalisasi dimana hampir semua jenis permainan dapat dimainkan melalui perangkat gadget (handphone, laptop, computer dan sebagainya).

Berdasarkan penelitian yang telah dilakukan sebelumnya, siswa yang diberikan materi permainan tradisional lebih aktif bergerak ketika jam pelajaran penjas (Nurohman \& Widiyatmoko, 2019). Dari hasil penelitian tersebut terlihat bahwa permainan tradisional merupakan salah satu media untuk membuat siswa lebih aktif dalam bergerak melalui pembelajaran penjas. Pendidikan jasmani dijadikan sebuah media untuk mengenalkan kembali permainan tradisional yang saat ini semakin tenggelam ditelan kemajuan digital. Oleh karena itu, penelitian ini bermaksud mengungkap partisipasi siswa sekolah dasar terhadap permainan tradisional Indonesia khususnya permainan tradisional daerah. 


\section{METODE PENELITIAN}

Penelitian ini merupakan penelitian deskriptif kuantitatif dengan menggunakan metode survey. Penelitian ini bertujuan untuk memberikan gambaran tentang perkembangan permainan tradisional di Jawa Tengah. Populasi dalam penelitian ini adalah siswa MI Nurul Yaqien Krasak Slaranglor dan sampel yang digunakan yaitu siswa kelas atas MI Nurul Yaqien. Teknik pengumpulan data dengan menggunakan Instrumen berupa kuisioner yang terdiri dari 25 butir pertanyaan. Peneliti menyebarkan kuisioner yang kemudia diisi oleh responden secara langsung. Analisis data yang dipergunakan adalah dengan penggunaan persentase atau disebut procentage correction, dan untuk memperoleh kesimpulan tiap-tiap komponennya harus dicari dulu persentase tiap-tiap sub komponen. Disamping itu juga divisualisasikan dalam bentuk tabel, hal ini dimaksudkan untuk mempermudah peneliti sendiri atau orang lain untuk memahami hasil penelitian (Arikunto, 2005).

\section{HASIL DAN PEMBAHASAN \\ Hasil}

Berdasarkan data yang diperoleh, pengetahuan dan pemahaman tentang permainan tradisional siswa MI Nurul Yaqien dapat dilihat pada table di bawah ini.

Tabel 1. Pengetahuan siswa Terhadap Permainan Tradisional

\begin{tabular}{llc}
\hline No. & Permainan Tradisional & Siswa MI (\%) \\
\hline 1 & Mengetahui & $94.44 \%$ \\
\hline 2 & Tidak Mengetahui & $5.56 \%$ \\
\hline
\end{tabular}

Pengetahuan tentang permainan tradisional merupakan tingkat awal untuk dapat berpartisipasi dalam permainan tradisional. Siswa MI Nurul Yaqien mengetahui dan memahami permainan tradisional, sebesar $94,44 \%$ dari berbagai sumber informasi . sumber informasi tersebut berasal dari teman, guru penjas, media cetak dan media elektronik. Pengetahuan tentang permainan tradisional meliputi definisi permainan tradisional, jenis permainan yang terdapat di Desa Krasak Slaranglor.

Diagram 1. Sumber Pengetahuan terhadap Permainan Tradisioal

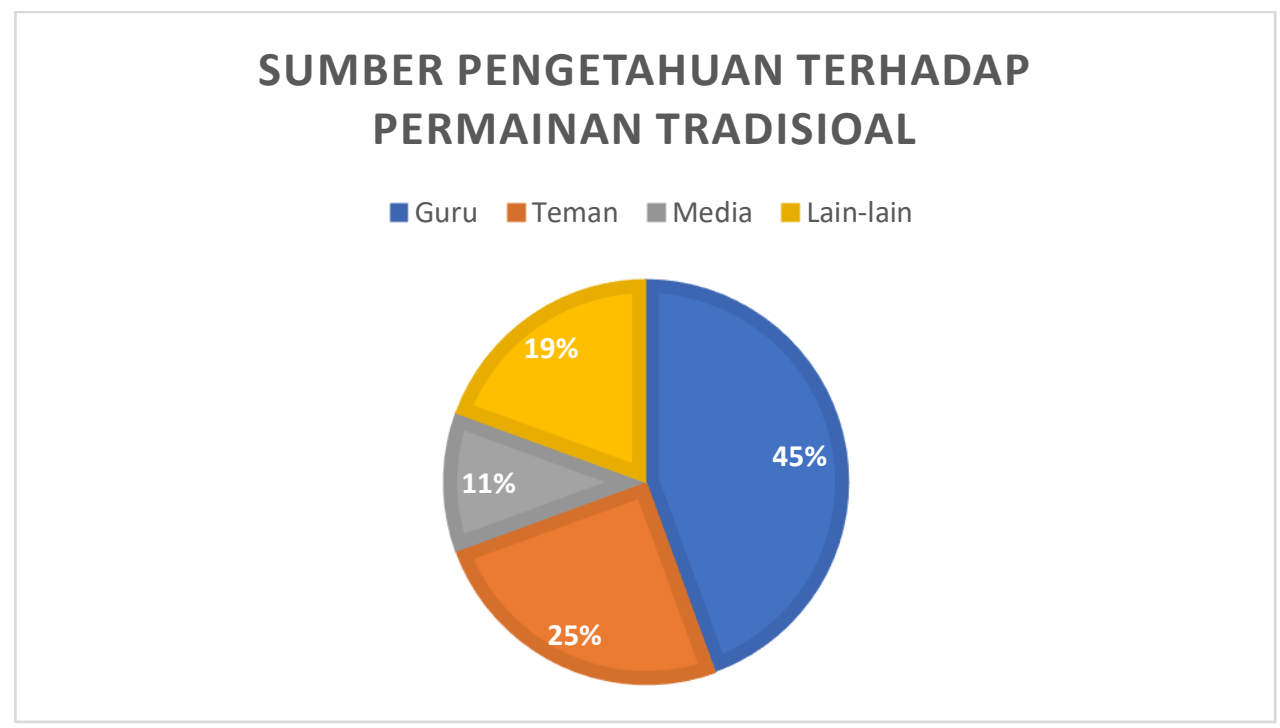

Untuk berpartisipasi aktif dalam permainan tradisional tidak cukup hanya dengan mengetahui permainan tradisional itu sendiri. Pemahaman terkait permainan 
tradisional menjadi factor penting keikitsertaan (partisipasi) masyarakat dalam permainan tradisional. Pemahaman berkaitan dengan kemampuan kognitif ditingkat selanjutnya dimana seseorang mampu mendeskripsikan dan mampu berpartisipasi aktif memainkan permainan tradisional.

Tabel 2. Pemahaman Siswa terhadap Permainan Tradisional

\begin{tabular}{llc}
\hline No. & Permainan Tradisional & Siswa MI (\%) \\
\hline 1 & Memahami & $71.43 \%$ \\
\hline 2 & Tidak Memahami & $28.57 \%$ \\
\hline
\end{tabular}

Berdasarkan data pada table 1 dan table 3, menunjukkan bahwa sebagian besar siswa telah mengetahui (94.44\%) permainan tradisional. Namun demikian pemahaman tentang permainan tradisional tidak sama besarnya. Siswa yang memahami permainan tradisional hanya sebagian (71.43\%). Sehingga terdapat $23.01 \%$ siswa yang telah mengetahui permainan tradisional tetapi belum memahami permainan tradisional itu sendiri.

Tabel 3. Keterlibatan dalam Permainan Tradisional

\begin{tabular}{llc}
\hline No. & Permainan Tradisional & Siswa MI $(\boldsymbol{\%})$ \\
\hline 1 & Terlibat & $91.67 \%$ \\
\hline 2 & Tidak terlibat & $8.33 \%$ \\
\hline
\end{tabular}

Berdasarkan data di atas, apabila dilakukan perbandingan, siswa yang mengetahui sebesar $94.44 \%$ siswa yang memahami sebesar $71.43 \%$, dan siswa yang terlibat sebesar $91.67 \%$ terdapat $2.77 \%$ siswa yang sudah mengetahui tetapi belum terlibat dalam permainan tradisional. Sebanyak $20.24 \%$ siswa belum memahami tetapi sudah terlibat dalam permainan tradisional.

\section{Pembahasan}

Permainan tradisional merupakan sarana bagi anak-anak dan masyarakat untuk melakukan aktivitas fisik. Melalui permainan tradisional anak dapat memiliki pengalaman gerak yang banyak sehingga dapat menunjang pertumbuhan dan perkembangan anak. Permainan tradisional juga merupakan sarana rekreasi bagi masyarakat. Permainan tradisional sudah dikenal sebagai warisan budaya bangsa dimana di dalamnya terkandung nilai-nilai luhur dari bangsa. Partisipasi masyarakat khususnya anak-anak belum dimaksimalkan dalam mempertahankan keberadaan permainan tradisional. Hal tersebut terlihat dari pengetahuan (94.44\%), pemahaman (71.43\%) dan keterlibatan (91.67)\% siswa MI
Nurul Yaqien terkait permainan tradisional. Tingginya angka pengetahuan, pemahaman dan keterlibatan siswa dalam permainan tradisional tidak terlepas dari peran guru dalam memperkenalkan dan mensosialisasikan permainan tradisional dalam kegiatan pembelajaran. Pendidikan jasmani menjadi salah satu wadah yang digunakan guru dalam memperkenalkan permainan tradisional. Permainan tradisional sering disisipkan dalam pembelajaran penjas di sekolah (Mega, Baitul, \& Arif, 2018). Tingginya pengetahuan dan keterlibatan siswa dalam mempertahankan keberlangsungan permainan tradisional menjadi modal yang sangat penting untuk menghidupkan kembali permainan tradisional di kalangan masyarakat yang saat ini sudah mulai tergerus kemajuan ilmu pengetahuan dan teknologi (IPTEK).

Era digitalisasi dan komputerisasi saat ini semakin membuat keberadaan permainan tradisional semakin terancam. Maraknya game online semakin membuat popularitas permainan tradisional semakin tenggelam. Anak-anak yang malas untuk bergerak 
cenderung memilih permainan yang tidak melibatkan aktivitas fisik yang banyak. Anakanak cenderung memilih duduk di depan televisi, komputer, laptop, handphone untuk bermain permainan. Sedentary behavior menyebabkan anak memiliki kecenderungan menderita obesitas dimana hal tersebut juga dapat menyebabkan peningkatan metabolic syndrome, bahkan mempengaruhi tingkat percaya diri dan kesehatan mental anak (Irfansyah, 2015).

Permainan tradisional merupakan suatu kegiatan yang menarik dan sangat istimewa. Permainan tradisional memiki pengaruh yang cukup besar terhadap pembentukan karakter anak dan memberikan dampak bagi perkembangan anak. Terdapat berbagai nilai positif dalam permainan tradisional antara lain mengembangkan kemampuan psikomotor, melatih kejujuran, kerjasama, melatih kemampuan negosiasi dan sosialisasi dengan lingkungan (Hikmah Prisia Yudiwinata \& Handoyo, 2014). Dengan kata lain, permainan tradisional memberikan dampak positif bagi pertumbuhan dan perkembangan anak. Melalui permainan tradisional anak memiliki kesempatan untuk memperoleh pengalaman gerak yang beragam. Oleh karena itu penting bagi anak-anak untuk melakukan aktivitas fisik melalui permainan tradisional.

Berdasarkan data sumber pengetahuan anak-anak terhadap permainan tradisional. Sebesar $44.45 \%$ siswa mengetahui permainan tradisional dari guru, $25 \%$ dari teman, $11.11 \%$ dari media dan $19.44 \%$ dari sumber lain. Dari hasil tersebut Peran guru khususnya guru pendidikan jasmani dalam memperkenalkan dan mensosialisasikan permainan tradisional menjaga sangat penting. Guru penjas menjadi tumpuan dalam mempertahankan eksistensi permainan tradisional karena permainan tradisional ini dapat disisipkan dalam kegiatan pembelajaran. Namun demikian, tugas mempertahankan eksistensi permainan tradisional tidak sepenuhnya dilimpahkan kepada guru. Perlu adanya kegiatan-kegitan atau metode-metode tertentu yang dapat mendongkrak eksistensi permainan tradisional, misalnya dengan promosi melalui media sosial atau menyelenggarakan kegiatan berupa lomba atau festival yang khusus diperuntukkan untuk permainan tradisional.

\section{SIMPULAN}

Berdasarkan hasil penelitian dan pembahas di atas dapat ditarik kesimpulan sebagai berikut: (1) hampir semua siswa mengetahui tentang permaian tradisional (94.44\%); (2) guru memegang peranan penting dalam memperkenalkan dan mensosialisasikan permainan tradisional di sekolah; (3) sebagian lebih siswa MI memahami tentang permainan tradisional (71.43\%); dan hampir semua siswa MI terlibat dalam permainan tradisional (91.67\%). Perkembangan permainan tradisional di MI Nurul Yaqien Krasak Slaranglor Tegal masih terjaga dengan baik. Hal tersebut terlihat dari tingginya presentase pengetahuan, pemahaman dan keterlibatan (partisipasi) siswa terhadap permainan tradisional. Keberlangsungan permainan tradisional menjadi hal yang perlu perhatian khusus dari semua pihak (masyarakat dan pemerintah. Perlu adanya sosialisasi berkala dan kegiatan-kegiatan yang dilaksanakan guna mendukung eksistensi permainan tradisional.

\section{UCAPAN TERIMA KASIH}

Terima kasih penulis sampaikan kepada Fakultas Ilmu Keolahragaan Universitas Negeri Semarang, semua anggota penelitian, dan MI Nurul Yaqien atas dukungannya sehingga penelitian ini dapat terselesaikan.

\section{DAFTAR PUSTAKA}

Akbari, H., Abdoli, B., Shafizadeh, M., Khalaji, H., Hajihosseini, S., \& Ziaee, V. (2009). The Effect of Traditional Games in Fundamental Motor Skill Development in 7-9 Year-Old Boys. Iranian Journal of Pediatrics, 19(2), 
123-129.

https://doi.org/10.1002/2017GL073681

Arikunto, S. (2005). Manajemen Penelitian. Jakarta: Rineka Cipta.

Aypay, A. (2016). Investigating The Role of Traditional Children' $s$ Games in Teaching Ten Universal Values in Turkey, (62), 283-300.

Boro, J., Daimary, R., \& Narzaree, B. (2015). Impact of Globalisation to Traditional Games and Recreation of the Bodos, 20(3), 87-91. https://doi.org/10.9790/0837-20338791

Charles, A. G., Abdullah, M. R., \& Musa, R. M. (2017). THE EFFECT OF TRADITIONAL GAMES INTERVENTION PROGRAMME IN THE ENHANCEMENT SCHOOLAGE CHILDREN ' S MOTOR SKILLS : A PRELIMINARY STUDY, 6(2), 157-169.

Effendi, A., \& Prihanto, J. B. (2014). PENGARUH PENGGUNAAN TEKNOLOGI INFORMASI TERHADAP AKTIVITAS FISIK SISWA ( Studi pada SMK Negeri 8 Surabaya Kelas X ) Ahmad Effendi Junaidi Budi Prihanto Abstrak. Jurnal Pendidikan Jasmani, 2(3), 605-608.

Hayati, S., CH, M., \& Asmawi, M. (2017). Effect Of Traditional Games, Learning Motivation and Learning Style on Childhoods Gross Motor Skill, 5(7), 5366.

Hikmah Prisia Yudiwinata, H. P., \& Handoyo, P. (2014). Permainan Tradisional dalam Budaya dan Perkembangan Anak. Paradigma, 2, 1-5. https://doi.org/S0025-326X(05)00576-X [pii] \r10.1016/j.marpolbul.2005.12.009

Irfansyah, U. Q. A. P. (2015). IDENTIFIKASI FAKTOR-FAKTOR PERMAINAN TRADISIONAL BEBENTENGAN SEBAGAI BASIS
PERANCANGAN GAME PEMICU PENINGKATAN SISTEM MOTORIK ANAK, 124-140.

Kovacevic, T., \& Opic, S. (2014). Contribution of Traditional Games to the Quality of Students' Relations and Frequency of Students' Socialization in Primary Education. Croatian Journal of Education-Hrvatski Casopis Za Odgoj I Obrazovanje, 16(1), 95-112.

Mega Anggita, G. (Universitas N. S., \& Amirullah Rachman, H. (Universitas N. Y. (2014). Jurnal Keolahragaan, Volume 2 - Nomor 2, 2014. Jurnal Keolahragaan, 2(1), 130-144.

Mega, G., Baitul, S., \& Arif, M. (2018). Eksistensi Permainan Tradisional Sebagai Warisan Budaya Bangsa.

Ngafifi, M. (2014). Advances in Technology and Patterns of Human Life in SocioCultural Perspective. Kemajuan Teknologi Dan Pola Hidup Manusia, 2(1), 33-47. https://doi.org/10.21831/JPPFA.V2I1.26 16

Nurohman, M., \& Widiyatmoko, F. A. (2019). Implementasi Permainan Tradisional Untuk Meningkatkan Keaktifan Gerak Siswa, 4(November 2018), 61-65. https://doi.org/10.26877/jo.v4i1.3028

Ode, L., Basri, A., Momo, A. H., Marhadi, A., Rahman, A., Ode, L., \& Jers, T. (2018). The Unsustainability of Kalego Traditional Game among Muna Community of Watopute District, 14(2), 12-17. https://doi.org/10.5539/ass.v14n2p12

Tedi, W. (2015). Perubahan Jenis Permainan Tradisional Menjadi Permainan Modern Pada Anak-Anak Di Desa Ijuk Kecamatan Belitang Hulu Kabupaten Sekadau the Traditional Games Changed in To Modern Games To the Children in Village Ijuk Belitang District of Hulu Sekadau. S-1 Sosiologi, 3(4), 1-17. 